\title{
Prevalence and Genetic Diversity of Grabloviruses in Free-Living Vitis spp.
}

\begin{abstract}
Elizabeth Cieniewicz, ${ }^{\dagger}$ Section of Plant Pathology and Plant-Microbe Biology, School of Integrative Plant Science, Cornell University, New York State Agricultural Experiment Station, Geneva, NY 14456; Jeremy R. Thompson, Heather McLane, and Keith L. Perry, Section of Plant Pathology and Plant-Microbe Biology, School of Integrative Plant Science, Cornell University, Ithaca, NY 14853; Gerald S. Dangl, Foundation Plant Services, University of California, Davis 95616; Quinlan Corbett, Finger Lakes Community College, Canandaigua, NY 14424; Timothy Martinson, Section of Horticulture, School of Integrative Plant Science, Cornell University, New York State Agricultural Experiment Station, Geneva, NY 14456; Alice Wise, Cornell Cooperative Extension, Long Island Horticultural Research and Extension Center, Riverhead, NY 11901; Anna Wallis, Section of Plant Pathology and Plant-Microbe Biology, School of Integrative Plant Science, Cornell University, New York State Agricultural Experiment Station and (formerly) Cornell Cooperative Extension, Eastern New York Commercial Horticulture, Plattsburg, NY 12901; James O'Connell, Cornell Cooperative Extension, Eastern New York Commercial Horticulture, Highland, NY 12528; Rick Dunst, Double A Vineyards, Fredonia, NY 14063; and Kerik Cox and Marc Fuchs, Section of Plant Pathology and Plant-Microbe Biology, School of Integrative Plant Science, Cornell University, New York State Agricultural Experiment Station
\end{abstract}

\begin{abstract}
The distribution and diversity of grapevine red blotch virus (GRBV) and wild Vitis virus 1 (WVV1) (genus Grablovirus; family Geminiviridae) were determined in free-living Vitis spp. in northern California and New York from 2013 to 2017. Grabloviruses were detected by polymerase chain reaction in 28\% (57 of 203) of samples from California but in none of the 163 samples from New York. The incidence of GRBV in free-living vines was significantly higher in samples from California counties with high compared with low grape production $\left(\chi^{2}=83.09\right.$; $P<0.001)$, and in samples near $(<5 \mathrm{~km})$ to compared with far $(>5 \mathrm{~km})$ from vineyards $\left(\chi^{2}=57.58 ; P<0.001\right)$. These results suggested a directional spread of GRBV inoculum predominantly from vineyards to freeliving Vitis spp. WVV1 incidence was also significantly higher in areas with higher grape production acreage $\left(\chi^{2}=16.02 ; P<0.001\right)$. However,

in contrast to GRBV, no differential distribution of WVV1 incidence was observed with regard to distance from vineyards $\left(\chi^{2}=0.88 ; P=0.3513\right)$ Two distinct phylogenetic clades were identified for both GRBV and WVV1 isolates from free-living Vitis spp., although the nucleotide sequence variability of the genomic diversity fragment was higher for WWV1 (94.3 to $99.8 \%$ sequence identity within clade 1 isolates and 90.1 to $100 \%$ within clade 2 isolates) than GRBV (98.3\% between clade 1 isolates and 96.9 to $100 \%$ within clade 2 isolates). Additionally, evidence for intraspecific recombination events was found in WVV1 isolates and confirmed in GRBV isolates. The prevalence of grabloviruses in California free-living vines highlights the need for vigilance regarding potential grablovirus inoculum sources in order to protect new vineyard plantings and foundation stock vineyards in California.
\end{abstract}

Grapevine red blotch disease is emerging as one of the most important viral diseases of Vitis spp. in North America (Cieniewicz et al. 2017a). Red blotch disease was described for the first time in 2008 in California as reddening of leaves with reports of reduced fruit qualities, similar to both the symptoms and ripening effects of leafroll disease. However, symptomatic vines tested negative for all known leafroll-associated viruses. Grapevine red blotch virus (GRBV) was found associated with disease symptoms (Al Rwahnih et al. 2013) and later demonstrated as the causative agent of red blotch disease in Vitis spp. (Yepes et al. 2018). GRBV infection disrupts berry development, inhibits ripening pathways (Blanco-Ulate et al. 2017), and threatens the productivity and profitability of vineyards (Cieniewicz et al. 2017a; Ricketts et al. 2017; Sudarshana et al. 2015).

GRBV is the type member of the genus Grablovirus in the family Geminiviridae (Varsani et al. 2017). This virus is widespread

${ }^{\dagger}$ Corresponding author: Elizabeth Cieniewicz; E-mail: ejc238@cornell.edu

Funding: This work was supported, in part, by the California Grape Rootstock Research Foundation, the California Grape Rootstock Improvement Commission, the American Vineyard Foundation, the California Department of Food and Agriculture, the New York Wine and Grape Foundation, United States Department of Agriculture-National Institute of Food and Agriculture (USDA-NIFA) Critical Agriculture Research and Extension award 201567028-23512, USDA-NIFA Hatch project number 1004285, and the College of Agriculture and Life Sciences, Cornell University. Q. Corbett was a recipient of a 2017 Nelson J. Shaulis summer research scholarship award.

*The $\boldsymbol{e}$-Xtra logo stands for "electronic extra" and indicates that one supplementary table and four supplementary figures are published online.

Accepted for publication 1 May 2018.

(C) 2018 The American Phytopathological Society in vineyards throughout the United States, likely due to its graft transmissibility and dissemination via infected propagation material (Krenz et al. 2014). Additionally, GRBV is vectored by the three-cornered alfalfa treehopper, Spissistilus festinus, as demonstrated in a greenhouse study (Bahder et al. 2016a). Spatiotemporal spread of red blotch disease was recently documented in a Vitis vinifera 'Cabernet franc' vineyard in California (Cieniewicz et al. 2017b) and the epidemiological role of S. festinus was illustrated (Cieniewicz et al. 2018).

GRBV was detected in free-living (feral) Vitis spp. near commercial vineyards in Napa County, California (Perry et al. 2016). Some of the infected free-living vines were hybrids of $V$. californica and $V$. vinifera (Perry et al. 2016). The presence of GRBV in free-living Vitis spp. in Napa County was later corroborated in an independent study (Bahder et al. 2016b). The notion of free-living Vitis spp. serving as inoculum reservoirs has been demonstrated in other grapevine pathosystems (Beach et al. 2017; Klaassen et al. 2011; Orel et al. 2017; Pacifico et al. 2016; Sabanadzovic 2009). Although vectormediated transmission of GRBV between free-living grapevines and commercial vineyards has not been confirmed, nor the direction of inoculum movement elucidated, the presence of GRBV in freeliving Vitis spp. suggests that uncultivated grapevines may be sources of virus inoculum.

Since the identification of GRBV, several gemini-like viruses have been discovered in Vitis spp., including wild Vitis virus 1 (WVV1) (Perry et al. 2018), grapevine geminivirus A (GGVA) (Al Rwahnih et al. 2017), and temperate fruit decay-associated virus (Basso et al. 2015). WVV1 is a putative member of the genus Grablovirus (Perry et al. 2018) along with the recently described Prunus geminivirus A (PrGVA) (Al Rwahnih et al. 2018) and the type species, GRBV (Al Rwahnih et al. 2018; Varsani et al. 2017). Unlike GRBV, WVV1 has only been detected in free-living Vitis spp.; it has not yet been detected in any Vitis cultivar or rootstock genotype. In addition, like GRBV, WVV1 is not associated with any disease symptoms in 
free-living Vitis spp. (Perry et al. 2016, 2018). To date, GRBV and WVV1 have only been described in free-living Vitis spp. in Napa County in California (Bahder et al. 2016b; Perry et al. 2016, 2018). Limited information is available on the distribution of both GRBV and WVV1 in free-living Vitis spp. in varied ecosystems. We investigated the prevalence and distribution of GRBV and WVV1 in free-living grape populations and hypothesized a directional movement of GRBV between cultivated and noncultivated plants. A related objective was to determine the genetic diversity of GRBV and WVV1 isolates in free-living Vitis spp. To address these objectives, we surveyed freeliving grapevines in close proximity to vineyards and also far from vineyards in both California and New York.

\section{Materials and Methods}

Collection of free-living Vitis spp. and genetic identification of California samples. Hardwood cuttings and leaf samples were collected from free-living Vitis spp. from 2013 to 2017 in the following counties in northern California: Butte, Glenn, Napa, Sacramento, Solano, Sonoma, and Sutter. These counties range from having high grape production (9.5 and 5.9\% acreage planted to grape in Napa and Sonoma counties) to very low grape production $(0.006,0.099$, and $0.017 \%$ acreage planted to grape in Sutter, Glenn, and Butte Counties, respectively). Samples were collected from free-living vines in or nearby riparian areas, primarily along the banks of the Sacramento River and Napa River, as well as along the banks of Maxwell Creek. A subset of California free-living Vitis spp. samples was genetically identified at Foundation Plant Services, University of California, Davis by using eight single-sequence repeat markers, as previously described (Dangl et al. 2015; Perry et al. 2016).

In New York, samples were collected from free-living Vitis spp. from March to August 2017 from the following counties: Chautauqua, Clinton, Ontario, Seneca, Steuben, Suffolk, Tompkins, Ulster, and Yates. These counties represent the major grape-growing regions of New York, including the Finger Lakes Region, Hudson Valley, Long Island, Champlain Valley, and Western New York. Sample collection in these counties was not restricted to riversides because free-living grapevines are more widely dispersed away from New York riparian areas compared with California.

An average of 20 free-living Vitis spp. samples were collected per county in both California and New York, except for Napa, Sacramento, and Ulster Counties, for which more samples were collected. In both California and New York, samples were selected either proximal to vineyards (less than $5 \mathrm{~km}$ distant) or away from vineyards (more than $5 \mathrm{~km}$ distant). No information was available on the health status of proximal vineyards when samples of free-living Vitis spp. were collected, with a few exceptions in Napa County, for which the presence of GRBV had been previously documented (unpublished data). Lignified wood with at least 15 buds was collected from individual freeliving grapevines and, if leaf tissue was available at the time of sampling, at least 10 leaves were collected in addition to lignified wood. Samples were collected from individual free-living grapevines at least $30 \mathrm{~m}$ from other free-living grapevines to avoid redundancy in sampling. Samples were stored at $4^{\circ} \mathrm{C}$ until virus testing.

Virus detection by polymerase chain reaction. Cambium scrapings and, if available, petiole tissue were removed from free-living grapevine samples using a razor blade and total plant DNA was extracted using the H.P. Plant DNA Kit (Omega Biotek, Norcross, GA) and stored at $-20^{\circ} \mathrm{C}$. Samples were tested for GRBV using diagnostic triplex polymerase chain reaction (PCR) with primers targeting a coat protein $(\mathrm{CP})$ gene fragment, a replicase-associated protein (Rep) gene fragment, and a Vitis 16S ribosomal DNA internal control (Krenz et al. 2014). The Repfor and Reprev primers initially designed for the amplification for the Rep fragment from GRBV also amplify the Rep fragment from WVV1 (Perry et al. 2018). However, the CPfor and CPrev primers initially designed for the amplification of a CP fragment from GRBV do not produce any fragment from WVV1 in PCR (Perry et al. 2018). Therefore, samples that yielded only the Rep fragment in the GRBV multiplex PCR were then assayed specifically for WVV1 using primers WVV1_CPfor (5'GATGAATCGAATTCTGAAAC-3') and WVV1_CPrev (5'-ATA
CATACTACTCACAGTCAATAC-3'). PCR were carried out with HotStar Plus polymerase (Qiagen, Carlsbad, CA) and manufacturersuggested conditions in a C1000 Touch Thermal Cycler (Bio-Rad Laboratories, Hercules, CA). DNA amplification products were resolved by electrophoresis on $2 \%$ agarose gels in $1 \times$ Tris-acetateEDTA buffer and stained with GelRED (Biotium, Fremont, CA).

Using PCR data, incidence of GRBV and WVV1 infection was determined for free-living grapevine populations in each county in California. The respective incidences of GRBV and WVV1 in free-living vines in each county were analyzed with regard to county grapevine production acreage and proximity to commercial grape production in an exploratory manner using $\chi^{2}$ tests in SAS (version 9.4; SAS Institute, Cary, NC).

QGIS map construction. California and New York county maps with GPS locations of free-living grapevines collected for this study were constructed using QGIS, desktop version 2.18.11. New York State civil boundary shapefiles were downloaded from New York GIS services website (New York State 2017). Percentage of acreage planted to grape was calculated for each county in New York using data from the United States Department of Agriculture-National Agriculture Statistics Service (USDA-NASS) and New York Department of Agriculture and Markets 2012 census for acreage of grape. For the California map, county shapefiles were downloaded from the U.S. Census Bureau's 2016 Master Address File/Topologically Integrated Geographic Encoding and Referencing database (California Open Data Portal 2017). Percentage of acreage planted to grape was calculated for each county in California using data from the USDA-NASS and California Department of Food and Agriculture 2016 grape acreage report (USDA-NASS and CDFA 2017).

For both California and New York, county shapefiles were styled with a graduated shading system using the percentage of acreage planted to grape in each county. GPS locations of free-living vines were included as a delimited text layer using coordinate reference system EPSG:4326 WGS 84 and styled by color according to infection status. To avoid overlap, point displacement was used with the following parameters: Concentric ring placement method, point distance tolerance of 0.0009 (map units), no displacement ring outline, and ring size adjustment of $0.05 \mathrm{~mm}$.

Characterization of the full-length genome of WVV1 isolates. Total nucleic acids were extracted from cambium scrapings or leaf petioles of samples that tested positive for WVV1 in PCR with a cetyltrimethylammonium bromide buffer and used in rolling circle amplification (RCA) to amplify circular DNA, as previously described (Krenz et al. 2014). RCA products were digested by restriction enzyme $K p n I$ to produce a full-length 3.2-kb fragment that was cloned into plasmid pUC19 (New England Biolabs, Ipswich, MA). For a single coinfected vine, restriction enzymes $K p n \mathrm{I}$ and $A v a \mathrm{I}$ were used for the digestion of GRBV and WVV1 RCA products, respectively. The resulting clones were transformed into Escherichia coli and sequenced at the Genomics Facility of the Cornell University Biotechnology Resource Center.

Genetic variability among GRBV and WVV1 isolates. The genetic variability of a subset of GRBV isolates from infected freeliving Vitis spp. was determined by sequencing PCR amplicons (744 bp) of the diversity fragment (i.e., a region spanning the origin of replication) with primers p1282-F and p1283-R (Perry et al. 2016). Primers WVV1divF (5'-GAGGGTATGTTAGGAAAAA-3') and WVV1divR (5'-GCAGCAGGCAAAGATAAATCC-3') were designed to PCR amplify a 739-bp diversity fragment from WVV1 isolates. GRBV and WVV1 DNA amplicons were resolved by electrophoresis, purified using ExoSAP-IT PCR Product Cleanup Reagent (Applied Biosystems, Foster City, CA), and sequenced at the Genomics Facility of the Cornell University Biotechnology Resource Center. Sequences were assembled using the DNASTAR Lasergene software suite, version 14.1.

GRBV and WVV1 sequences from this study or previously determined (Perry et al. 2016, 2018) are available in GenBank and listed in Table 1. Sequences were aligned using ClustalW (Larkin et al. 2007). Recombination detection analyses were performed on the WVV1 and GRBV diversity fragment alignments, as well as the WVV1 
full-length genome alignment, using the RDP4 software (Martin et al. 2015). Recombination events were considered to be significant if at least three of seven recombination detection methods found evidence for recombination with $P<0.05$ (Krenz et al. 2014). The reticulate nature of the phylogenies resulting from recombination was confirmed by computing $\Delta$ scores, as well as applying the $\varphi$ test for overall recombination detection in SplitsTree4 (Huson and Bryant 2006). The $\Delta$ score and Q-residual value $=0$ if distances between taxa fit a tree exactly, inferring no recombination, whereas $\Delta$ score and Q-residual values $=1$ if relationships are absolutely reticulate in nature, inferring a high degree of recombination. Scores range from 0 (tree-like) to 1 (nontreelike) (Huson and Bryant 2006).

Maximum-likelihood phylogenies (RaxML) with recombinant regions removed were constructed in RDP4. To provide further indication of genetic variability among GRBV and WVV1, a pairwise identity matrix of WVV1 and GRBV diversity fragment sequences was constructed using the Sequence Demarcation Tool, version 1.2 (Muhire et al. 2014). Sequences were aligned using MUSCLE (Edgar 2004).

\section{Results}

Grablovirus detection in free-living grapevines. In California, GRBV was detected in 21.2\% (43 of 203) of the free-living Vitis spp. collected between 2014 and 2017 (Table 2; Fig. 1). None of the infected samples exhibited disease symptoms. Genetic fingerprinting of a subset of GRBV-infected samples from California identified them as hybrids of $V$. californica $\times V$. vinifera or hybrids of $V$. californica $\times$ rootstock genotypes (Table 1). In New York, no grabloviruses were detected in any of the 163 free-living grapevine samples tested, regardless of their proximity to production vineyards

Table 1. California grapevine red blotch virus (GRBV) and wild Vitis virus 1 (WVV1) isolates used in this study

\begin{tabular}{|c|c|c|c|c|c|}
\hline Virus & Isolate & County & Sequence type & GenBank accession number & Citation \\
\hline GRBV & NY1290a & Napa & Diversity fragment & MG976051 & This study \\
\hline GRBV & NY1292 & Napa & Diversity fragment & MG976052 & This study \\
\hline GRBV & NY1314 & Napa & Diversity fragment & MG976053 & This study \\
\hline GRBV & NY1319b & Napa & Diversity fragment & MG976054 & This study \\
\hline GRBV & NY1361 & Napa & Diversity fragment & MG976055 & This study \\
\hline GRBV & NY1425 & Napa & Diversity fragment & MG976056 & This study \\
\hline GRBV & NY1465 & Napa & Diversity fragment & MG976057 & This study \\
\hline GRBV & NY1467 & Napa & Diversity fragment & MG976058 & This study \\
\hline GRBV & NY1614 & Napa & Diversity fragment & MG976059 & This study \\
\hline GRBV & NY1615 & Napa & Diversity fragment & MG976060 & This study \\
\hline GRBV & EFD1 & Sacramento & Diversity fragment & MG976061 & This study \\
\hline GRBV & EFD2 & Sacramento & Diversity fragment & MG976062 & This study \\
\hline GRBV & EFD5 & Sacramento & Diversity fragment & MG976063 & This study \\
\hline GRBV & EFD6 & Sacramento & Diversity fragment & MG976064 & This study \\
\hline GRBV & Elkhorn5 & Sacramento & Diversity fragment & MG976065 & This study \\
\hline GRBV & ERP1 & Sacramento & Diversity fragment & MG976066 & This study \\
\hline GRBV & $\mathrm{F} 2$ & Sacramento & Diversity fragment & MG976067 & This study \\
\hline GRBV & IKEA2 & Sacramento & Diversity fragment & MG976068 & This study \\
\hline GRBV & NY1606 & Sacramento & Diversity fragment & MG976069 & This study \\
\hline GRBV & NY1607 & Sacramento & Diversity fragment & MG976070 & This study \\
\hline GRBV & Solano_16 & Solano & Diversity fragment & MG976071 & This study \\
\hline GRBV & Solano_17 & Solano & Diversity fragment & MG976072 & This study \\
\hline GRBV & Solano_20 & Solano & Diversity fragment & MG976073 & This study \\
\hline GRBV. & Sonoma_25 & Sonoma & Diversity fragment & MG976074 & This study \\
\hline GRBV & Sonoma_29 & Sonoma & Diversity fragment & MG976075 & This study \\
\hline GRBV & Sonoma_34 & Sonoma & Diversity fragment & MG976076 & This study \\
\hline GRBV & Sonoma_37 & Sonoma & Diversity fragment & MG976077 & This study \\
\hline GRBV & Canal2 & Sutter & Diversity fragment & MG976078 & This study \\
\hline GRBV & NY699 & Napa & Full-length genome & KU564247 & Perry et al. 2016 \\
\hline GRBV & NY700 & Napa & Full-length genome & KU564248 & Perry et al. 2016 \\
\hline GRBV & NY913 & Napa & Full-length genome & KU564254 & Perry et al. 2016 \\
\hline GRBV & NY175 & Napa & Full-length genome & KF147916 & Krenz et al. 2014 \\
\hline GRBV & NY358 & Napa & Full-length genome & JQ901105 & Krenz et al. 2014 \\
\hline WVV1 & Glenn_5 & Glenn & Diversity fragment & MG976079 & This study \\
\hline WVV1 & Sonoma_27 & Sonoma & Diversity fragment & MG976080 & This study \\
\hline WVV1 & Sonoma_33 & Sonoma & Diversity fragment & MG976081 & This study \\
\hline WVV1 & Solano_7 & Solano & Full-length genome & MG976082 & This study \\
\hline WVV1 & Solano_8 & Solano & Full-length genome & MG976083 & This study \\
\hline WVV1 & Solano_19 & Solano & Full-length genome & MG976084 & This study \\
\hline WVV1 & NY1325d & Napa & Full-length genome & MF185004 & Perry et al. 2018 \\
\hline WVV1 & NY1358 & Napa & Full-length genome & MF185005 & Perry et al. 2018 \\
\hline WVV1 & NY1424e & Napa & Full-length genome & MF185006 & Perry et al. 2018 \\
\hline WVV1 & NY1466 & Napa & Full-length genome & MF185007 & Perry et al. 2018 \\
\hline WVV1 & NY1467 & Napa & Full-length genome & MF185008 & Perry et al. 2018 \\
\hline WVV1 & NY1468 & Napa & Full-length genome & NC035480 & Perry et al. 2018 \\
\hline WVV1 & NY1468 & Napa & Full-length genome & MF185009 & Perry et al. 2018 \\
\hline WVV1 & NY1616 & Napa & Full-length genome & MF185010 & Perry et al. 2018 \\
\hline
\end{tabular}

a The plant host is an F1 hybrid of Vitis californica $\times$ rootstock 'Ruggeri 140' (V. berlandieri $\times$ V. rupestris).

$\mathrm{b}$ The plant host is an F1 hybrid of $V$. californica $\times V$. vinifera 'Syrah or Durif'.

c The plant host is an F1 hybrid of $V$. californica $\times$ rootstock $V$. rupestris 'St. George'.

$\mathrm{d}$ The plant host is a $V$. californica.

e The plant host is an F1 hybrid of $V$. californica $\times V$. vinifera 'Cabernet Sauvignon'. 
(Supplementary Table S1; Supplementary Fig. S1). Based on morphological characteristics, New York samples were V. riparia, $V$. aestivalis, V. labrusca, or hybrids derived thereof.

GRBV prevalence was higher in free-living grapevines in the California counties rated as having high commercial grapevine production (3.8 to $9.5 \%$ of total county acreage planted to grape) than in counties rated as having low grapevine production $(0.006$ to $0.73 \%$ of total acreage planted to grape) $\left(\chi^{2}=83.09 ; P<0.001\right)$ (Fig. 1). When considering individual counties, GRBV incidence was

Table 2. Grablovirus detection in free-living Vitis spp. in California ${ }^{a}$

\begin{tabular}{lcccc}
\hline County & Distance $^{\mathbf{b}}$ & GRBV $^{\mathbf{c}}$ & WVV1 $^{\mathbf{d}}$ & Coinfection $^{\mathbf{e}}$ \\
\hline Napa & $<5 \mathrm{~km}$ & $24 / 83$ & $9 / 83$ & $1 / 83$ \\
& $>5 \mathrm{~km}$ & $\mathrm{na}$ & $\mathrm{na}$ & $\mathrm{na}$ \\
Sacramento & $<5 \mathrm{~km}$ & $8 / 23$ & $0 / 23$ & $0 / 23$ \\
& $>5 \mathrm{~km}$ & $2 / 8$ & $0 / 8$ & $0 / 8$ \\
Sonoma & $<5 \mathrm{~km}$ & $5 / 23$ & $2 / 23$ & $0 / 23$ \\
& $>5 \mathrm{~km}$ & $\mathrm{na}$ & $\mathrm{na}$ & $\mathrm{na}$ \\
Solano & $<5 \mathrm{~km}$ & $2 / 8$ & $1 / 8$ & $0 / 8$ \\
& $>5 \mathrm{~km}$ & $1 / 12$ & $2 / 12$ & $0 / 12$ \\
Sutter & $<5 \mathrm{~km}$ & $1 / 5$ & $0 / 5$ & $0 / 5$ \\
& $>5 \mathrm{~km}$ & $0 / 14$ & $0 / 14$ & $0 / 14$ \\
Butte & $<5 \mathrm{~km}$ & $\mathrm{na}$ & $\mathrm{na}$ & $\mathrm{na}$ \\
& $>5 \mathrm{~km}$ & $0 / 15$ & $0 / 15$ & $0 / 15$ \\
Glenn & $<5 \mathrm{~km}$ & $\mathrm{na}$ & $\mathrm{na}$ & $\mathrm{na}$ \\
& $>5 \mathrm{~km}$ & $0 / 12$ & $1 / 12$ & $0 / 12$ \\
\hline
\end{tabular}

${ }^{\mathrm{a}}$ Abbreviation: $\mathrm{na}=$ not applicable.

${ }^{\mathrm{b}}$ Relative distance of free-living Vitis spp. samples from vineyards: 0 to $5 \mathrm{~km}$ $(<5 \mathrm{~km})$ and more than $5 \mathrm{~km}(>5 \mathrm{~km})$.

${ }^{c}$ Number of free-living vines testing positive for grapevine red blotch virus (GRBV) over the total number of samples tested.

d Number of free-living vines testing positive for wild Vitis virus 1 (WVV1) over the total number of samples tested.

${ }^{\mathrm{e}}$ Coinfection by GRBV and WVV1. significantly higher in Napa (29\%, 24 of 83), Sonoma (22\%, 5 of $23)$, and Sacramento $(32 \%, 10$ of 31$)$ compared with Solano $(15 \%$, 3 of 20) and Sutter (5\%, 1 of 19) Counties $\left(\chi^{2}=22.79 ; P<\right.$ 0.001). Infected free-living Vitis spp. samples in Napa, Sonoma, and Sacramento Counties were identified both close (within 30 to $5 \mathrm{~km}$ ) to and far (more than $5 \mathrm{~km}$ ) from vineyards, although the GRBV incidence was higher in samples near vineyards $(28 \%, 40$ of 142) compared with far from them $(5 \%, 3$ of 61$)\left(\chi^{2}=57.58 ; P<\right.$ 0.001) (Table 2). GRBV was not detected in any of the free-living vines collected in Glenn and Butte Counties, two counties with extremely low commercial grape production (less than $0.1 \%$ of the total acreage) and not bordering counties with major viticulture acreage (Fig. 1). GRBV-infected samples in Solano County were less than $10 \mathrm{~km}$ away from vineyards in Napa County, a neighboring county with the highest acreage planted to grape (Fig. 1). The single GRBV-infected free-living Vitis sp. sample from Sutter County is an exception because it was far from any production vineyard but close to nursery vineyards.

WVV1 was detected in 7\% (15 of 203) of the California free-living grapevines collected between 2014 and 2017. Similar to GRBV incidence, WVV1 incidence was higher in counties with the highest commercial grapevine production $\left(\chi^{2}=16.02 ; P<0.001\right)$. None of the infected samples exhibited virus-like symptoms. The virus was found in Napa (11\%, 9 of 83), Sonoma (9\%, 2 of 23), and Solano (15\%, 3 of 20) but not in Sacramento, Sutter, and Butte Counties, and only one sample from Glenn County tested positive for WVV1 (Table 2). There were no differences in WVVI incidence based on proximity to commercial vineyards $\left(\chi^{2}=0.88 ; P=0.3513\right)$. A single freeliving Vitis sp. sample from Napa County was infected with both WVV1 and GRBV (Table 2). Based on morphological characteristics, the plant hosts were either $V$. californica or hybrids of $V$. californica. Subsequently, genetic fingerprinting of two WVV1infected samples revealed that one sample was pure $V$. californica and the other was a hybrid of $V$. californica and $V$. vinifera 'Cabernet Sauvignon' (Table 1).

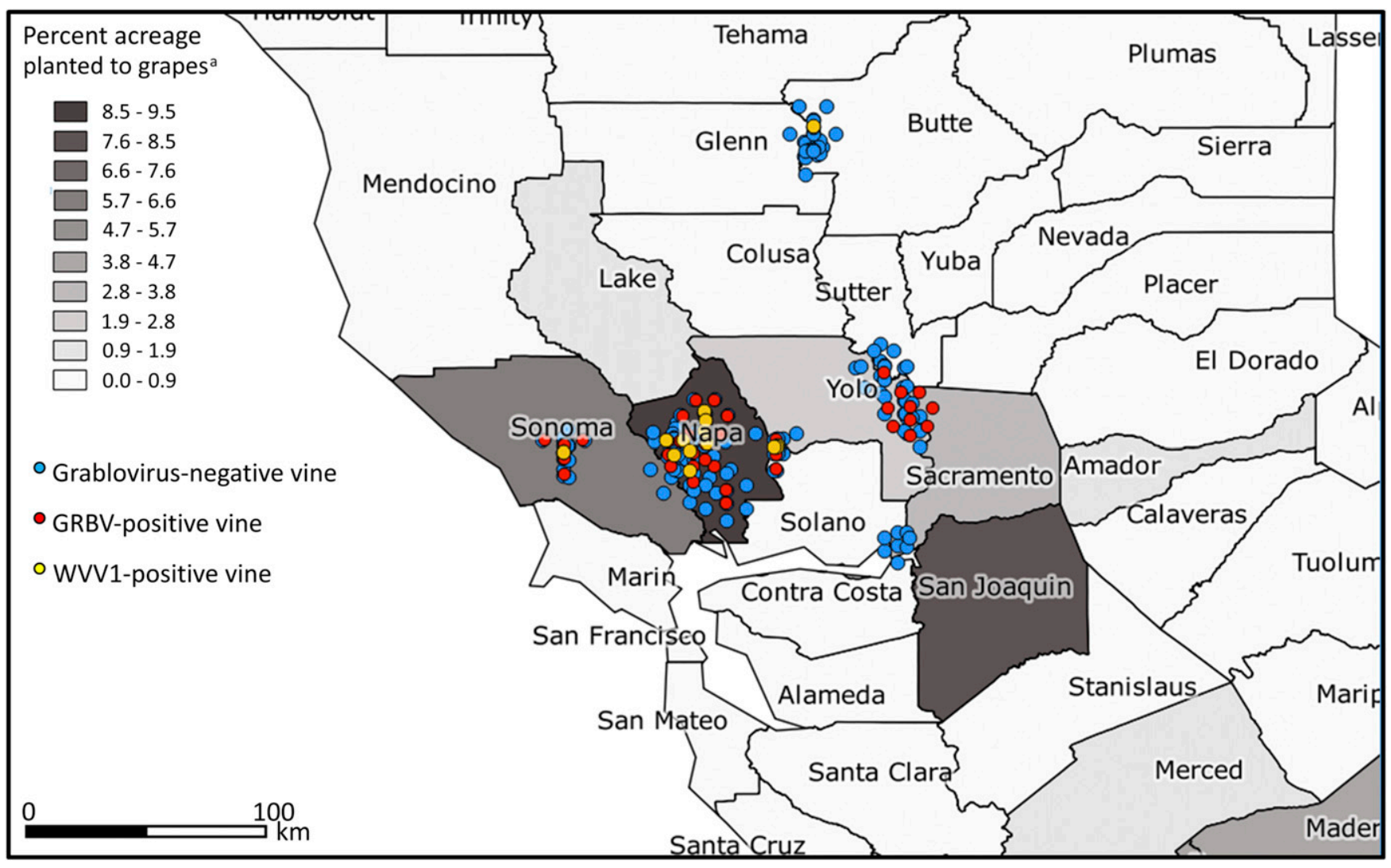

Fig. 1. Map of northern California counties showing the density of acreage planted to grapevine, along with the locations and infection status of free-living vines collected for this study. Map was constructed in QGIS, desktop version 2.18.11. Point displacement was used to avoid overlapping points for the locations of free-living vines. 
Two distinct lineages and evidence for recombination for WVV1 isolates. Phylogenetic analyses of the full-length genome sequence of 13 WVV1 isolates from California, including three new complete sequences determined in this study (Table 1), revealed two distinct lineages (Supplementary Fig. S2). The between-clade nucleotide sequence identity varied from 93.3 to
94.7\%. The within-clade 1 nucleotide sequence identity ranged from 96.7 to $99.8 \%$ and the within-clade 2 nucleotide sequence identity ranged from 94.7 to $99.6 \%$. WVV1 isolates from clade 2 were from free-living grapevines sampled in Napa County, while clade 1 isolates were all derived from free-living grapevines in Solano County.

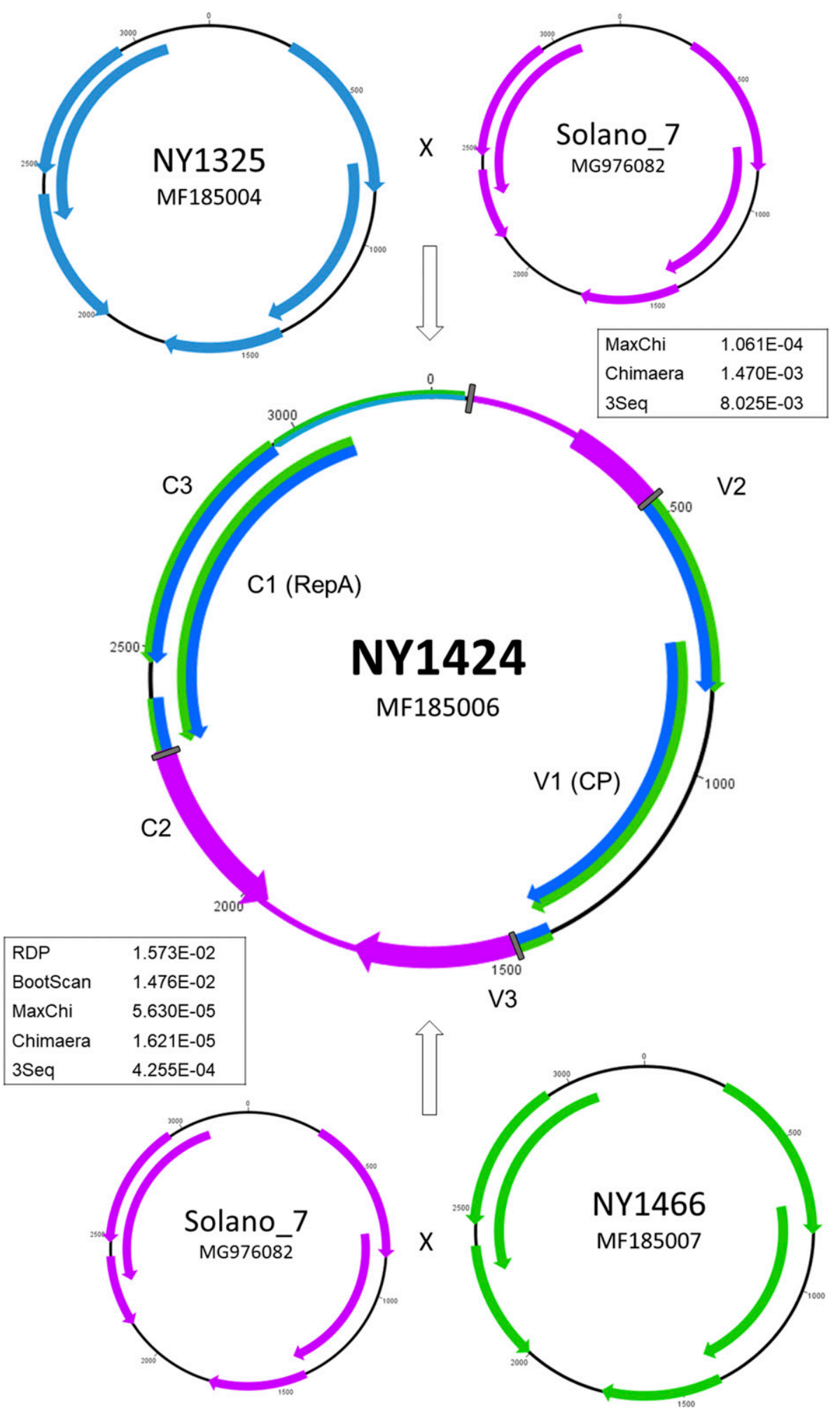

Fig. 2. Recombination events in wild Vitis virus 1 (WVV1) isolate NY1424 (GenBank accession number MF185006). Recombination event number 1 is between major parental isolate NY1325 (larger, blue arrows, MF185004) and minor parental isolate Solano_7 (smaller, purple arrows, MG976082). Recombination event number 2 is between major parental isolate NY1466 (larger, green arrows, MF185007) and minor parental isolate Solano_7 (smaller, purple arrows, MG976082). The region flanking the origin of replication of WVV1 isolate NY1424 belongs to the major parent for each of the two recombination events. Recombination detection methods and associated $P$ values are indicated in boxes next to the respective recombination events. 
RDP4 analyses applied to the alignment of full-length WVV1 genome sequences revealed isolate Napa_NY1424 as a probable recombinant. Three of seven methods (MaxCHI, CHIMAERA, and 3SEQ) found evidence of recombination event 1 , and five of seven methods (RDP, BOOTSCAN, MaxCHI, CHIMAERA, and 3SEQ) found evidence of recombination event 2 for isolate Napa_NY1424. The average $P$ values for each recombination event were less than 0.05 (Fig. 2). Recombination event 1 has a possible major parent in isolate Napa_NY1325 (96.1\% similarity) and a minor parent isolate in Solano_7 (92.2\% similarity), with probable breakpoints at nucleotide positions 74 and 474 . Recombination event 2 has a possible major parent in isolate Napa_NY1466 (96.7\% similarity) and a minor parent in isolate Solano_7 (95.4\% similarity), with probable breakpoints at nucleotide positions 1,475 and 2,306, with Napa_NY1424 as the reference isolate (Fig. 2). The $\varphi$ test in SplitsTree4 confirmed a high likelihood of recombination among WVV1 full-length genome sequences $(P<0.01)$. The $\Delta$ score was 0.1881 and the Q-residual score was 0.002715 , indicating reticulation among the sequences and supporting the occurrence of recombination.

Phylogenetic analyses using the diversity fragment alignment containing three additional WVV1 isolates from Glenn and Sonoma Counties resulted in a tree topology that reflected two distinct lineages of WVV1 isolates (Fig. 3). This result was consistent with the phylogenetic tree obtained with full genome sequences. Two isolates from Sonoma County (Sonoma_25 and Sonoma_33) are in clade 2 with isolates from Napa County. The single isolate from Glenn County (Glenn_5) is in clade 1 with isolates from Solano County (Fig. 3). The WVV1 genomic diversity fragments have 94.3 to $99.8 \%$ sequence identity among isolates within clade 1 and 90.1 to $100 \%$ sequence identity among isolates within clade 2 .
RDP4 analyses support the chimeric nature of isolate Napa NY1424 with isolate Napa_NY1467 (95.7\% similarity) as a potential major parent and an unknown minor parent detected in three of seven recombination detection methods (MaxCHI, $P=2.042 \mathrm{E}-04$; CHIMAERA, $P=2.033 \mathrm{E}-03$; and 3SEQ, $P=2.558 \mathrm{E}-03$ ), with breakpoints at nucleotide positions 194 and 542 in the alignment. RDP4 analyses further provided evidence for recombination in the diversity fragment sequence of isolate Napa_NY1325, with isolate Napa_ NY1468 (94.5\% similarity) as a potential major parent and isolate Sonoma_33 (96.5\% similarity) as a potential minor parent in three of seven analyses (MaxCHI, $P=1.008 \mathrm{E}-02$; CHIMAERA, $P=$ 1.077E-02; and 3SEQ, $P=3.442 \mathrm{E}-02$ ), with breakpoints at nucleotide positions 594 and 112 in the alignment. The $\varphi$ test in SplitsTree4 confirmed a high likelihood of recombination among WVV1 genomic diversity fragment sequences $(P<0.01)$. The $\Delta$ score was 0.1426 and the Q-residual score was 0.02136 , indicating reticulation among the sequences and supporting the occurrence of recombination.

Two distinct phylogenetic lineages of GRBV isolates and evidence for recombination. Phylogenetic analyses of the genomic diversity fragment nucleotide sequence of GRBV isolates from free-living Vitis spp. revealed two distinct clades (Fig. 4). The majority of GRBV isolates, including all those from Napa, Sonoma, and Solano Counties and most from Sacramento County, belong to clade 2 , in which the nucleotide sequence identity ranged from 96.9 to $100 \%$. One isolate from Sacramento County and the only isolate from Sutter County grouped in clade 1, with $98.3 \%$ nucleotide sequence identity. The nucleotide sequence identity between clades 1 and 2 ranged from 88.3 to $90.9 \%$. Evidence for recombination was detected in isolates Sonoma_34 and Sacramento_F2, both in clade 2. A single recombination event was detected in three of seven

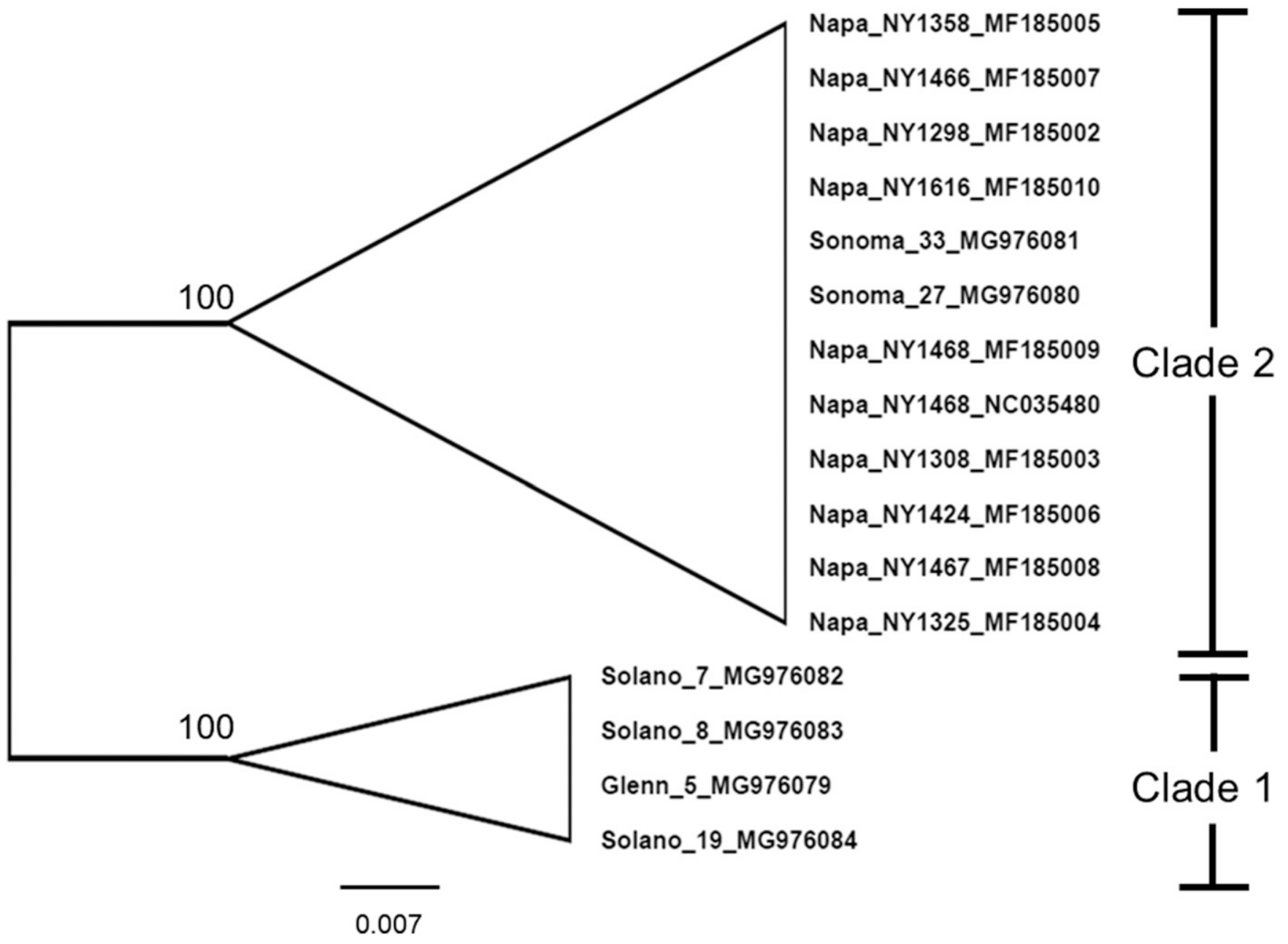

Fig. 3. Maximum-likelihood phylogeny of wild Vitis virus 1 diversity fragment nucleotide sequences of isolates from free-living Vitis spp. in California. Numbers at branches indicate bootstrap support $(1,000$ bootstrap replicates, random seed $=3)$. Branches with less than $70 \%$ bootstrap support were collapsed. 
RDP4 methods (MaxCHI, $P=1.645 \mathrm{E}-02$; SiScan, $P=3.665 \mathrm{E}-02$; and $3 \mathrm{SEQ}, P=2.081 \mathrm{E}-02$ ) for the diversity fragment sequence of isolate Sonoma_34. The potential major parent is unknown (Napa NY1290 was used for analyses) and the minor parent is isolate Napa_NY1361 (98.8\% similarity), with breakpoints at nucleotide positions 210 and 472. Similarly, isolate Sacramento_F2 is a recombinant identified by four of the seven RDP4 methods (MaxCHI, $P=1.409 \mathrm{E}-04$; Chimaera, $P=1.693 \mathrm{E}-03$; SiScan, $P=$ 5.530E-03; and 3Seq $P=1.835 \mathrm{E}-04$ ), with isolate Napa_NY1361 ( $99.7 \%$ similarity) as a potential major parent and an unknown minor parent isolate (Sonoma_34 used for analyses), and breakpoints at nucleotide positions 216 and 449 in the alignment. The $\varphi$ test did find evidence of recombination among the GRBV genomic diversity fragment sequences $(P=5.122 \mathrm{E}-9)$. The $\Delta$ score was 0.1664 and the Q-residual score was $4.359 \mathrm{E}-4$, indicating reticulation among the sequences and supporting the occurrence of recombination.

Grablovirus diversity in free-living vines in California. A pairwise identity matrix, including the genomic diversity fragments of WVV1 and GRBV together, provided additional evidence for the presence of two groups of isolates for both WVV1 and GRBV. The pairwise identity matrix confirmed a higher nucleotide sequence variability for WVV1 compared with GRBV isolates (Supplementary Fig. S3).

When considering a representative isolate from each clade of WVV1 and GRBV, the V1 open reading frame (ORF), putatively encoding the $\mathrm{CP}$, is the most highly conserved ORF of grabloviruses at the amino acid level (78.6 to $79 \%$ ), as previously reported (Perry et al. 2018), and the second most highly conserved ORF at the nucleotide level (70.5 to $70.8 \%$ ), with $\mathrm{C} 3$ being the most conserved ORF at the nucleotide level (Supplementary Fig. S4).

\section{Discussion}

This study expands on previous research reporting the detection of GRBV in free-living grapevines near a Cabernet franc vineyard in Napa County, CA (Perry et al. 2016) and in other areas of Napa County (Bahder et al. 2016b). Here, GRBV was detected in free- living Vitis spp. in most California counties surveyed, primarily in those where grape production is substantial (3.8 to 9.5\% acreage planted to grapevine). Because spread of GRBV has been documented in California (Cieniewicz et al. 2017b), the discovery of GRBV in free-living vines stimulates questions on the direction of spread of GRBV between free-living Vitis spp. and vineyards, whether from commercial vineyards to uncultivated grapevines or vice versa. To approach this question, we sampled free-living grapevines throughout northern California counties both within major viticulture areas and also far from grape production areas in Glenn and Butte Counties, where walnut, almond, and rice production predominate (CDFA 2016).

Our findings suggest a directional movement of GRBV predominantly from commercial vineyards to free-living vines. This hypothesis is supported by the higher incidence of GRBV in free-living vines in counties with more grapevine production, as well as the lack of GRBV in counties far from vineyard production in California. It is also supported by a significantly higher GRBV incidence in uncultivated vines near $(<5 \mathrm{~km})$ vineyards $(28 \%, 40$ of 142) compared with those far $(>5 \mathrm{~km})$ from vineyards $(5 \%, 3$ of 61$)$. Additionally, characterizing the genetic variability of the genomic diversity fragments demonstrated that the majority of GRBV isolates were in phylogenetic clade 2 and only two isolates were in clade 1 . A similar pattern of a dominant clade 2 was described for GRBV isolates from both commercial vineyards (Krenz et al. 2014) and insect vector candidates in an infected vineyard (Cieniewicz et al. 2018).

It is plausible that GRBV clade 2 predominates in vineyards due to widespread dissemination of infected propagation material, with less widespread dissemination of GRBV clade 1 genetic variants. Finding a similar pattern of genetic variant dispersal among isolates from free-living vines supports the hypothesis that GRBV inoculum is moving predominantly from vineyards to free-living vines. In contrast, thus far, WVV1 has only been detected in free-living grapevines, where the distribution of isolates would not be directly influenced by human activity (i.e., dissemination of infected propagation material). This might explain the higher degree of genetic

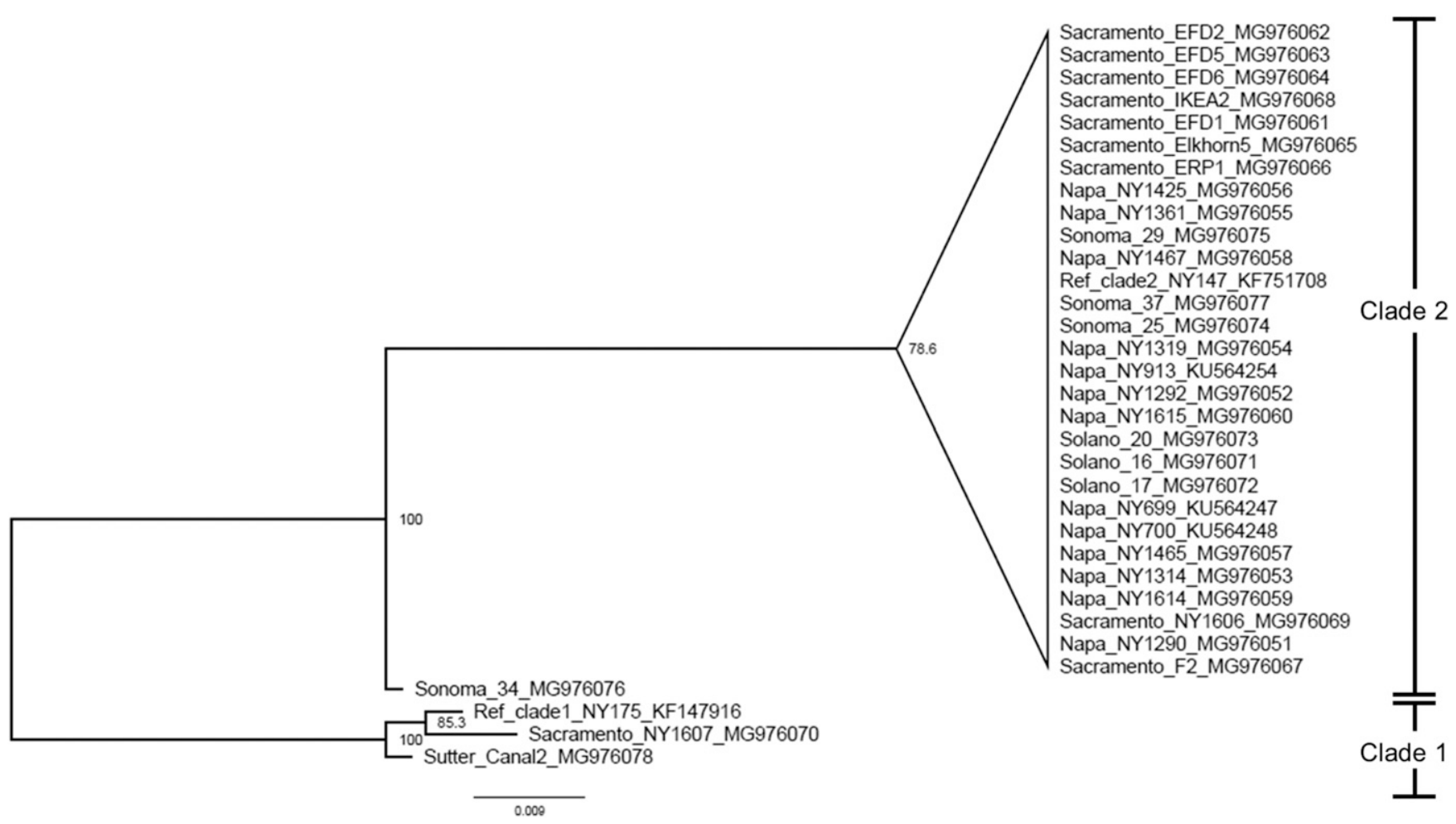

Fig. 4. Maximum-likelihood phylogeny of grapevine red blotch virus diversity fragment nucleotide sequences of isolates from free-living Vitis spp. in California. Recombinant regions corresponding to the contribution of the minor parent were removed from isolates Sonoma_34 and Sacramento_F2 for phylogenetic analyses. Numbers at branches indicate bootstrap support (1,000 bootstrap replicates). Branches with less than 70\% bootstrap support were collapsed. 
diversity among WVV1 isolates in comparison with GRBV. The hypothesized directional movement of GRBV predominantly from vineyards to free-living grapevines is further strengthened by the perceived absence of GRBV in free-living vines in New York, where GRBV incidence in vineyards is low and there is no evidence of secondary spread (unpublished data).

Although the findings of this study allow us to postulate that the predominant direction of GRBV inoculum movement is from commercial vineyards to free-living vines in California, the potential of free-living vines to serve as an inoculum source should not be discounted. This is particularly important to consider if efforts are made to remove an infected vineyard in California and replant with vines derived from clean, virus-tested stocks, as is currently recommended (Cieniewicz et al. 2017a). Free-living vines infected with GRBV could also be a source of inoculum if grown proximal to nursery operations, where even infrequent introductions of the virus could potentially go unnoticed and result in large-scale dissemination in propagated vines.

Thus far, WVV1 has only been detected in free-living grapevines in Napa, Sonoma, Solano, and Glenn Counties in California. Although $S$. festinus has been identified as a GRBV vector (Bahder et al. 2016a) of epidemiological significance (Cieniewicz et al. 2018), no insect vector has yet been identified for WVV1. Therefore, the method by which free-living Vitis spp. become infected with WVV1 remains unknown. The importance of this research is highlighted by the amino acid sequence identity of 78.6 to $79 \%$ between the presumptive GRBV and WVV1 CP encoded by the V1 ORF (Perry et al. 2018). Because vector specificity and competency is dependent on the sequence of the $\mathrm{CP}$ in geminiviruses (Briddon et al. 1990), it is possible that WVV1 and GRBV are both vectored by S. festinus or, alternatively, that WVV1 is vectored by a related membracid. Transmission assays are needed to determine whether WVV1 can be transmitted by an insect vector. Additionally, the possibility that grabloviruses are transmitted by seed cannot be discounted, knowing that some begomoviruses (Geminiviridae) are seed transmitted (Anabestani et al. 2017; Kil et al. 2016, 2017; Kim et al. 2015; Kothandaraman et al. 2016). Thus, it is possible that some free-living vines became infected by GRBV or WVV1 via seed transmission rather than vector transmission. More work is needed to determine whether GRBV and WVV1 are seed transmissible. Interestingly, a single case of mixed WVV1 and GRBV infection was identified in Napa County. Based on our current knowledge of grablovirus transmission, it is uncertain how this free-living vine became infected by GRBV and WVV1 but presumably by vector or seed transmission.

The implications of GRBV-infected free-living Vitis spp. in the epidemiology of red blotch disease are not well understood. Similarly, limited information is available on the phenology of the known insect vector, $S$. festinus, in vineyard ecosystems. In at least one instance in California, spread of GRBV occurred most rapidly in vineyard areas where initial inoculum is aggregated (Cieniewicz et al. 2017b). Management of red blotch disease is limited to preventive measures and the use of planting material derived from clean, virus-tested (negative) stocks. Effective sanitation practices in vineyards are better informed by a greater awareness of inoculum sources in and around vineyards. As previously described, frequent scouting for red blotch disease symptoms and removal of infected vineyards is crucial for prevention of GRBV spread (Cieniewicz et al. 2017a,b, 2018; Sudarshana et al. 2015). Results of this study suggest that removal of any free-living Vitis spp. proximal to vineyard sites should be considered for replants in Napa, Sonoma, Sacramento, and Solano Counties. Similar recommendations apply to foundation stock vineyards in these counties.

It is unknown whether WVV1 causes disease in cultivated grapevines such as $V$. vinifera. Nonetheless, considering the genetic relatedness of WVV1 with GRBV (Perry et al. 2018) and the impact of GRBV on vineyard profitability (Cieniewicz et al. 2017a; Ricketts et al. 2017; Sudarshana et al. 2015), learning more about the distribution, biology, and ecology of WVV1 is of interest to fill a gap in knowledge about grabloviruses. For example, determining the host range and transmission mode of both GRBV and WVV1 is critical for a comprehensive understanding of grablovirus epidemiology. Assuming that WVV1 spread to cultivated vines can occur and the virus has similar detrimental effects on production and fruit quality as its very close relative, GRBV, we may be provided with the first example of a grapevine virus (WVV1) with the potential for a proactive management approach, rather than a reactive response to a newly discovered and potentially emerging virus. In any event, eliminating free-living Vitis spp. proximal to production and foundation stock vineyards in Napa, Sonoma, Sacramento, and Solano Counties should become part of a comprehensive portfolio of grablovirus management strategies.

\section{Literature Cited}

Al Rwahnih, M., Alabi, O., Westrick, N. M., Golino, D., and Rowhani, A. 2017. Description of a novel monopartite geminivirus and its defective subviral genome in grapevine. Phytopathology 107:240-251.

Al Rwahnih, M., Alabi, O., Westrick, N., and Golino, D. 2018. Prunus geminivirus A: A novel Grablovirus infecting Prunus spp. Plant Dis. 103:1246-1253.

Al Rwahnih, M., Ashita, D., Anderson, M., Rowhani, A., Uyemoto, J. K., and Sudarshana, M. R. 2013. Association of a DNA virus with grapevines affected by red blotch disease in California. Phytopathology 103:10691076.

Anabestani, A., Behjatnia, S., Izadpanah, K., Tabein, S., and Accotto, G. 2017 Seed transmission of beet curly top virus and beet curly top Iran virus in a local cultivar of petunia in Iran. Viruses 9:299.

Bahder, B. W., Zalom, F. G., Jayanth, M., and Sudarshana, M. R. 2016a Phylogeny of geminivirus coat protein sequences and digital PCR aid in identifying Spissistilus festinus (Say) as a vector of Grapevine red blotchassociated virus. Phytopathology 106:1223-1230.

Bahder, B. W., Zalom, F. G., and Sudarshana, M. R. 2016b. An evaluation of the flora adjacent to wine grape vineyards for the presence of alternative host plants of Grapevine red blotch-associated virus. Plant Dis. 100:1571-1574.

Basso, M., da Silva, J., Fajardo, T., Fontes, E., and Zerbini, F. 2015. A novel, highly divergent ssDNA virus identified in Brazil infecting apple, pear and grapevine. Virus Res. 210:27-33.

Beach, S., Kovens, M., Hubbert, L., Honesty, S., Guo, Q., Pap, D., Dai, R., Kovacs, L., and Qiu, W. 2017. Genetic and phenotypic characterization of Grapevine vein clearing virus from wild Vitis rupestris. Phytopathology 107: 138-144.

Blanco-Ulate, B., Hopfer, H., Figueroa-Balderas, R., Ye, Z., Rivero, R. M., Albacete, A., Pérez-Alfocea, F., Koyama, R., Anderson, M. M., Smith, R. J., Ebeler, S. E., and Cantu, D. 2017. Red blotch disease alters grape berry development and metabolism by interfering with the transcriptional and hormonal regulation of ripening. J. Exp. Bot. 68:1225-1238.

Briddon, R. W., Pinner, M. S., Stanley, J., and Markham, P. G. 1990. Geminivirus coat protein gene replacement alters insect specificity. Virology 177:85-94.

California Open Data Portal. 2017. CA Geographic Boundaries. Online publication. https://data.ca.gov/dataset/ca-geographic-boundaries

CDFA. 2016. California Agricultural Statistics Review, 2015-2016. Online publication. California Department of Food and Agriculture. https://www. cdfa.ca.gov/statistics/PDFs/2016Report.pdf

Cieniewicz, E. J., Loeb, G., Pethybridge, S., Perry, K. L., and Fuchs, M. F. 2018 Insights into the ecology of grapevine red blotch virus in a diseased vineyard. Phytopathology 108:94-102.

Cieniewicz, E. J., Perry, K. L., and Fuchs, M. 2017a. Grapevine red blotch: Molecular biology of the virus and management of the disease. Pages 303-314 in: Grapevine Viruses: Molecular Biology, Diagnostics and Management. B. Meng, G. P. Martelli, D. Golino, and M. Fuchs, eds. Springer Verlag, Berlin.

Cieniewicz, E. J., Pethybridge, S. J., Gorny, A., Madden, L. V., McLane, H., Perry, K. L., and Fuchs, M. F. 2017b. Spatiotemporal spread of grapevine red blotchassociated virus in a California vineyard. Virus Res. 241:156-162.

Dangl, G. S., Mendum, M. L., Yang, J., Walker, M. L., and Preece, J. E. 2015 Hybridization of cultivated Vitis vinifera with wild $V$. californica and V. girdiana in California. Ecol. Evol. 5:5671-5684.

Edgar, R. C. 2004. MUSCLE: Multiple sequence alignment with high accuracy and high throughput. Nucleic Acids Res. 32:1792-1797.

Huson, D. H., and Bryant, D. 2006. Application of phylogenetic networks in evolutionary studies. Mol. Biol. Evol. 23:254-267.

Kil, E.-J., Kim, S., Lee, Y.-J., Byun, H.-S., Park, J., Seo, H., Kim, C.-S., Shim, J.-K., Lee, J.-H., Kim, J.-K., Lee, K.-Y., Choi, H.-S., and Lee, S. 2016. Tomato yellow leaf curl virus (TYLCV-IL): A seed-transmissible geminivirus in tomatoes. Sci. Rep. 6: Article 19013.

Kil, E.-J., Park, J., Choi, E.-Y., Byun, H.-S., Lee, K.-Y., An, C. G., Lee, J.-H., Lee, G.-S., Choi, H.-S., Kim, C.-S., Kim, J.-K., and Lee, S. 2017. Seed transmission of Tomato yellow leaf curl virus in sweet pepper (Capsicum annuum). Eur. J. Plant Pathol. 150:759-764.

Kim, J., Kil, E.-J., Kim, S., Seo, H., Byun, H.-S., Park, J., Chung, M.-N., Kwak, H.-R., Kim, M.-K., Kim, C.-S., Yang, J.-W., Lee, K.-Y., Choi, H.-S., and Lee, S. 2015. Seed transmission of Sweet potato leaf curl virus in sweet potato (Ipomoea batatas). Plant Pathol. 64:1284-1291. 
Klaassen, V. A., Sim, S. T., Dangl, G. S., Osman, F., Al Rwahnih, M., Rowhani, A., and Golino, D. A. 2011. Vitis californica and Vitis californica $\times$ Vitis vinifera hybrids are hosts for Grapevine leafroll-associated virus-2 and -3 and Grapevine virus A and B. Plant Dis. 95:657-665.

Kothandaraman, S. V., Devadason, A., and Ganesan, M. V. 2016. Seed-borne nature of a begomovirus, Mung bean yellow mosaic virus in black gram. Appl. Microbiol. Biotechnol. 100:1925-1933.

Krenz, B., Thompson, J., McLane, H., Fuchs, M. F., and Perry, K. L. 2014. Grapevine red blotch-associated virus is widespread in the United States. Phytopathology 104:1232-1240.

Larkin, M. A., Blackshields, G., Brown, N. P., Chenna, R., McGettigan, P. A., McWilliam, H., Valentin, F., Wallace, I. M., Wilm, A., Lopez, R., Thompson, J. D., Gibson, T. J., and Higgins, D. G. 2007. ClustalW and ClustalX version 2. Bioinformatics 23:2947-2948.

Martin, D. P., Murrell, B., Golden, M., Khoosal, A., and Muhire, B. 2015. RDP4: Detection and analysis of recombination patterns in virus genomes. Virus Evol. 1:vev003.

Muhire, B. M., Varsani, A., and Martin, D. P. 2014. SDT: A virus classification tool based on pairwise sequence alignment and identity calculation. PLoS One 9:e108277.

New York State. 2017. NYS Civil Boundaries. Online publication. GIS Data Set Details. http://gis.ny.gov/gisdata/inventories/details.cfm?DSID=927

Orel, D. C., Reid, C. L., Fuchs, M., and Burr, T. J. 2017. Identifying environmental sources of Agrobacterium vitis in vineyards and wild grapevines. Am. J. Enol. Vitic. 68:213-217.

Pacifico, D., Stigliano, E., Sposito, L., Spinelli, P., Garfì, G., Gristina, A. S., Fontana, I., and Carimi, F. 2016. Survey of viral infections in spontaneous grapevines from natural environments in Sicily. Eur. J. Plant Pathol. 145:189-197.
Perry, K. L., McLane, H., Hyder, M. Z., Dangl, G. S., Thompson, J. R., and Fuchs, M. F. 2016. Grapevine red blotch-associated virus is present in free-living Vitis sp. proximal to cultivated grapevines. Phytopathology 106:663-670.

Perry, K. L., McLane, H., Thompson, J. R., and Fuchs, M. 2018. A novel grablovirus from non-cultivated grapevine (Vitis sp.) in North America. Arch. Virol. 163:259-262.

Ricketts, K., Gómez, M., Fuchs, M., Martinson, T., Smith, R., Cooper, M., Moyer, M., and Wise, A. 2017. Mitigating the economic impact of grapevine red blotch: Optimizing disease management strategies in U.S. vineyards. Am. J. Enol. Vitic. 68:127-135.

Sabanadzovic, S. 2009. Viruses of native Vitis germplasm in the Southeastern United States. Pages 32-35 in: Ext. Abstr. 16th Meet. Int. Counc. Study of Viruses and Virus-Like Dis. Grapevine, Dijon, France.

Sudarshana, M. R., Perry, K. L., and Fuchs, M. F. 2015. Grapevine red blotchassociated virus, an emerging threat to the grapevine industry. Phytopathology 105:1026-1032.

USDA-NASS and CDFA. 2017. Grape Acreage Report 2016 Crop. Online publication. United States Department of Agriculture-National Agricultural Statistics Service and California Department of Food and Agriculture. https:// www.nass.usda.gov/Statistics_by_State/California/Publications/Specialty_and_ Other_Releases/Grapes/Acreage/2017/201704grapeacres.pdf.

Varsani, A., Roumagnac, P., Fuchs, M., Navas-Castillo, J., Moriones, E., Idris, A., Briddon, R. W., Rivera-Bustamante, R., Murilo Zerbini, F., and Martin, D. P. 2017. Capulavirus and Grablovirus: Two new genera in the family Geminiviridae. Arch. Virol. 162:1819-1831.

Yepes, L. M., Cieniewicz, E., Krenz, B., McLane, H., Thompson, J. R., Perry, K. L., and Fuchs, M. 2018. Causative role of Grapevine red blotch virus in red blotch disease. Phytopathology 108:902-909. 